\title{
Effect of Fenugreek (Trigonella foenum-gracum L.) Seed Powder as Natural Feed Additive on Performance and Blood Parameters of Broiler Chicks
}

\author{
B.S. Gaikwad ${ }^{1 *}$, R.A. Patil ${ }^{2}$, P.V. Padghan ${ }^{3}$ and S.S. Shinde ${ }^{3}$ \\ Department of Animal Husbandry and Dairy Science, \\ College of Agriculture, Latur 413512, India \\ *Corresponding author
}

\section{A B S T R A C T}

\section{Keywords}

Growth performance, Hematological parametrs, Serum lipid profile

\section{Article Info}

Accepted:

10 September 2019

Available Online:

10 October 2019
An experiment was conducted on the effects of Fenugreek (Trigonella foenum-gracum.L) seed powder as a natural feed additive on performance, hematological parameters and serum constituents of broilers. Fenugeek seed powder was supplemnted standard broiler ration as a $\mathrm{T}_{1}$ (control), $\mathrm{T}_{2}, \mathrm{~T}_{3}$ and $\mathrm{T}_{4}$ in the four different diets. Eighty, day-old broiler chicks were randomly divided into four equal groups having 20 chicks in each treatment and four replicate of 5 birds reared in deep litter system feed offered a standard broiler diet $\left(\mathrm{T}_{1}\right)$ and fenugreek seed powder addition in the diet of broilers @ 0.5\% $\left(\mathrm{T}_{2}\right), 1.0 \%\left(\mathrm{~T}_{3}\right)$ and $1.5 \%\left(\mathrm{~T}_{4}\right)$ on dry matter basis by partial of control diet for 42 days. Fenugreek seed powder supplemeted $\left(\mathrm{T}_{4}\right) 1.5 \%$ highest live weight is observed $(2636.12 \mathrm{~g})$ in this group. Fenugreek seed powder at the $1.5 \%$ level significantly $(\mathrm{P}<0.05)$ improved the body weight, feed consumption but $1 \%$ fenugreek seed powder improves hematological and serum profile of broilers. There was significant $(\mathrm{P}<0.05)$ hematological parameters $\mathrm{WBC}$, Lymphocytes, Monocytes, MCH, MCHC in this parameters all values are increased as compare to control. But RBC, Hemoglobin decreses the value as compare to control group in fenugreek seed powder supplemented birds. However, non-significant $(\mathrm{P}>0.05)$ variation was observed in Granulocytes, PLT (platlet) values was increased but in MCV values are decresed as compare control group diet. There was significant $(\mathrm{P}<0.05)$ differences in seum profile observed in Glucose, HDL-Cholesterol values was incresed but decreased in Triglycerides as compare to control group, however, non singificant $(\mathrm{P}<0.05)$ observed Cholesterol values was decreased in $1 \%$ supplemented group but LDLCholesterol, HDL-LDL ratio values were increased as compare to control group.The results from the present study, it could be concluded that the use of fenugreek seed powder as a feed additive at the level of 1 per cent as it improved the significantly hematolgical parameter and serum lipid profile.

\section{Introduction}

The broiler sector has been the most dynamic sector of poultry production due to its marginal investments and quick returns.
Broiler is very fast growing birds.Because of fast growth rate the birds undergo in a heavy metabolic stress. To release the stress, some sorts of antioxidants are required, as antioxidant prevents cellular damage. Some of 
the dietary plant sources have antioxidants such as carotenoids, phenolic acids, flavonoids.

Large number of feed additives available for inclusion in animal and poultry diets to improve animal performance. However, the use of chemical products especially hormones and antibiotics, may cause unfavorable side effects. Moreover, there is evidence indicating that this products could be considered as pollutants for human and threaten their health on the long-run. Attempts to use the natural materials such as medical plants could be widely accepted as feed additives to improve the efficiency of feed utilization and animal productive performance (Aboul-Fotouh et al., 1999).

Fenugreek seed powder is used as a feed additive in the production of preserved meat.

Owing to the seed content of mucilage, it helps relieve sore throttle and is useful in the treatment of asthma and difficult breathing and is considered an appetizer and helps in digestion. Fenugreek seeds have also been recognized as a potential source of diosgenin, a basic compound in the hemisynthesis of steroidal sapogenins such as cortisone and sex hormones.

Previously it has also been reported to have anti-microbial, hypoglycaemic, hypolipidemic, hypochloesteremic and antioxidant effects of an animal's. Duru et al., (2013) and Nazar and Tinay (2007) reported that its seed contained $28.4 \%$, protein, $9.3 \%$, crude fibre and crude fat $7.1 \%$. Fenugreek seeds contain $7.5 \%$ total lipids, of which neutral lipids constituted $84.1 \%$, glycolipids $5.4 \%$ and phospholipids $10.5 \%$. Whole fenugreek seed contains about 1.7-4.8\% saponins. It also benefits the digestive system as a laxative, intestinal lubricant, carminative, anti-emetic, digestive and tonic helps to dissolve fat and a cholesterol deposit prevent fat accumulation and water retention and helps to lower blood sugar levels.

\section{Materials and Methods}

Eighty, day old, commercial straight run broiler chicks (Vencobb-430) strain was obtained from Huma-hatcheries, Latur (Maharashtra). All the experimental chicks were individually weighed wing banded and then randomly distributed in to four treatments of 20 chicks with four replication of 5 chicks in each treatment on similar body weight basis. All the experimental chicks were reared for 42 days on deep litter system in a wellventilated shed. Proper brooding of chicks was done by providing sufficient heat and light by using electric bulbs in each treatment for first three weeks of age. The standard temperature of brooding was $32-35^{\circ} \mathrm{C}$ for first week. A weekly reduction of $3^{0} \mathrm{C}$ was done till brooder temperature reaches to $27^{\circ} \mathrm{C}$ by third week of age. Afterword sufficient artificial light was provided during night hours throughout the experimental period.

Fresh, clean and cool drinking water was provided to bird's ad-labitum. All the precautionary measures against diseases were taken throughout the experimental period of six weeks. The dietary treatments $\mathrm{T}_{1^{-}} 100$ parts of standard broiler ration without supplement (control group), $\mathrm{T}_{2^{-}} 99.5$ parts of standard broiler ration +0.5 Parts of fenugreek seed powder, $\mathrm{T}_{3^{-}} 99.00$ parts of standard broiler ration +1.00 Parts of fenugreek seed powder and $\mathrm{T}_{4^{-}} 98.5$ part standard broiler ration +1.5 Parts of fenugreek seed powder. All the broiler chicks were fed with ground maize first two days of age.

Chicks feed standard feed purchased from market for three periods of 2-10 days birds fed with pre-starter, 11-21 days birds fed with broiler starter and 22-42 days birds fed with 
broiler finisher. The diets were fed ad-libitum to experimental groups by adding required amount of fenugreek seed powder as per treatment. The per cent ingredient composition of experimental broiler ration that is for prestarter, starter and finisher in Table 1 respectively.

All birds were weighed individually after their arrival from the hatchery to the experimental farm (initial weight) and weekly body weights were recorded accurately in morning hours by withdrawing feeding troughs. At the end of experiment one bird was purposely selected from each replication based on average group weight. Three $\mathrm{ml}$ blood was collected from wing vein using vacuum tubes containing potassium salts of ethylene diamine tetra acetate (EDTA) as anticoagulant.

The hematological studies were carried out at local Pathological Laboratories and Diagnostic Institute. Estimate the following hematological parameters A) White Blood Cells 1)Lymphocytes 2) Monocytes 3) Granulocytes B) Red Blood Cells C) Hemoglobin D) Hematocrit E) Mean corpuscle volume F) Mean corpuscular Hemoglobin G) Mean corpuscular Hemoglobin Concentration H) Platelet. At the end of experiment three $\mathrm{ml}$ blood was collected from wing vein in syringe without any anticoagulant and kept in clot activator tubes.

The serum constituents parameter were determined, estimate following blood serum parameters. 1) Glucose 2) Serum Cholesterol 3) Serum Triglycerides 4) Serum HDL i.e. (High density Lipoprotein) 5) Serum LDL i. e. (Low density Lipoprotein) 6) HDL/LDL ratio. The treatment wise data on cumulative body weight,hematological parameters and blood serum constituents were subjected to analysis of variance of complete randomized design (Snedecor and Cochran 1982).

\section{Results and Discussion}

\section{Growth performance of broilers}

\section{Cumulative body weights}

The average weekly growth performance of experimental birds at body weight of broilers from day old to sixth weeks of age in all dietary treatments were subjected to CRD and the results are presented in Table 2. The statistical analysis on the weekly body weight of broiler birds under four different treatments during each week revealed significant $(\mathrm{P}<0.05)$ difference during all the weeks except initial, first and second week. After the sixth week it was observed from the average cumulative body weights of broiler birds in the treatment group $\mathrm{T}_{3}$ and $\mathrm{T}_{4}$ were significantly $(\mathrm{P}<0.05)$ higher as compared to those in $T_{1}$ and $T_{2}$ group. The average body weight of $2636.12 \mathrm{~g}$ obtained in $\mathrm{T}_{4}$ group was significantly superior over $\mathrm{T}_{1}(2536.47 \mathrm{~g})$ and those in $\mathrm{T}_{2}(2573.53 \mathrm{~g})$ group. The growth pattern indicated that optimum beneficial effect of fenugreek seed powder supplementation as an herbal feed additive could be achieved at 1.5 per cent level of inclusion but 1 per cent was economical because 1 per cent and 1.5 per cent levels were at par with each other. The improvement in body weights of birds in all fenugreek powder diet group was observed. It may be due to the presence of essential fatty acids and high quality proteins in the fenugreek seeds and stimulating effect of the digestive system might in turn lead to improve body weights and performance.

The results of present study were similar with Elbushra. (2012) who showed that the weekly gain in body weight of broiler chicks receiving 1.5 per cent fenugreek seed powder was significantly $(\mathrm{P}<0.05)$ higher as compared to control, group receiving 0.5 per cent and those in group receiving 1 per cent fenugreek seed powder. 
Similar trend was also observed by Weerasingha and Atapattu (2013) who reported the same result as the weekly live body weight of fenugreek fed 1 per cent fenugreek seed powder group of broiler remained significantly $(\mathrm{P}<0.05)$ higher than that of control group. Mamoun et al., (2014) also revealed that chicks fed on $1 \%$ FSP recorded significantly $(\mathrm{P}<0.05)$ higher body weight compared to all tested groups, while those fed on control diet recorded significantly lower body weight.Bhale (2015) also noticed similar results with present study that addition of $1 \%$ germinated fenugreek seed powder in broiler ration exhibited better weight than without germinated fenugreek seed powder. Khadr and Abdel-Fattah (2007) indicated that addition of fenugreek seeds during the growing period had slightly increased body weight gain for chicks fed diets containing $1 \%$ fenugreek seeds followed by those fed $2 \%$ as compared to control diet.

\section{Hematological parameter}

The results are presented in Table 3. The analysis of variance showed significant $(\mathrm{P}<0.05)$ effect of feeding fenugreek on the hematological parameters at the end of sixth week for treatment groups $T_{1}, T_{2}, T_{3}$ and $T_{4}$. The WBC (White blood cells) count in blood of broilers was 121.83, 122.28, 129.68 and $130.51\left(\times 10^{3} \mu \mathrm{l}\right)$ in $\mathrm{T}_{1}, \mathrm{~T}_{2}, \mathrm{~T}_{3}$ and $\mathrm{T}_{4}$ groups respectively. Out of these broiler birds of $\mathrm{T}_{4}$ $(1.5 \%)$ showed significant superior over than other groups.

The LYM (Lymphocytes) (Volume) values in broilers of $\mathrm{T}_{3}$ and $\mathrm{T}_{4}$ group showed significantly higher LYM than other groups. In case of MON (Monocytes) (Volume) birds of $\mathrm{T}_{3}$ group had significantly $(\mathrm{P}<0.05)$ higher volume than $T_{1}, T_{2}$ and $T_{4}$ groups. In case of GRA (Granulocytes) (Volume) birds of $\mathrm{T}_{4}$ group had higher volume than $\mathrm{T}_{1}, \mathrm{~T}_{2}$ and $\mathrm{T}_{3}$ groups.
The RBC (Red blood cells) count was 2.44, $2.14,2.10$ and $2.05\left(\times 10^{6} / \mathrm{ul}\right)$ in $\mathrm{T}_{1}, \mathrm{~T}_{2}, \mathrm{~T}_{3}$ and $\mathrm{T}_{4}$ groups respectively.Out of which the $\mathrm{T}_{1}$ showed significantly higher RBC than other groups.The $\mathrm{Hb}$ (Hemoglobin) value in $\mathrm{T}_{1}$ control group showed significantly higher $\mathrm{Hb}$ than other groups.The HCT (Hematocrit) value in blood parameter $T_{1}$ control group was significantly superior than other groups. The MCV (Mean corpuscle volume) value was 137.96, 134.58, 133.55 and 133.11 (fl)in $\mathrm{T}_{1}$, $\mathrm{T}_{2}, \mathrm{~T}_{3}$ and $\mathrm{T}_{4}$ groups, respectively.

The MCH (Mean corpuscle hemoglobin) value was $32.06,39.73,39.85$ and $32.14 \mathrm{pg}$ in $\mathrm{T}_{1}, \mathrm{~T}_{2}, \mathrm{~T}_{3}$ and $\mathrm{T}_{4}$ groups respectively out of which birds of $T_{2}$ and $T_{3}$ showed significantly higher $\mathrm{MCH}$ than other groups. The $\mathrm{MCHC}$ (Mean corpuscle hemoglobin concentration) value was $37.76,37.50,37.86$ and $39.35 \mathrm{~g} / \mathrm{dl}$ in $\mathrm{T}_{1}, \mathrm{~T}_{2}, \mathrm{~T}_{3}$ and $\mathrm{T}_{4}$ groups, respectively out of these $\mathrm{T}_{4}$ showed significantly higher MCHC than other groups. The PLT (Platelet) count in blood of broilers was 187.50, 318, 225.63 and $245.25\left(\times 10^{3} / \mathrm{ul}\right)$ in $\mathrm{T}_{1}, \mathrm{~T}_{2}, \mathrm{~T}_{3}$ and $\mathrm{T}_{4}$ groups, respectively.Out of which $T_{2}$ showed higher PLT than other groups.

The present results were similar to Yatoo et. al. (2012) who reported that there were significantly $(\mathrm{P}<0.05)$ higher values of all the blood parameters in treatment groups provided with fenugreek seed powder compared to control group. Similar results were obtained by Abdul-Rahman (2012), and Bhaisare et al., (2014) who suggested that there were significantly $(\mathrm{P}<0.05)$ higher values of blood parameters such as $\mathrm{Hb}, \mathrm{PCV}$ and TEC in treatment groups over control group. However the results disagreed with JavedYasar et al., (2012) who reported that total leukocyte count (TLC) remained unaltered after supplementation of fenugreek in the broiler ration. 
Table.1 Chemical composition of experimental broiler ration

\begin{tabular}{|l|l|l|l|l|}
\hline \multirow{2}{*}{$\begin{array}{l}\text { Sr. } \\
\text { No. }\end{array}$} & \multirow{2}{*}{ Nutrients } & \multicolumn{3}{|l|}{ Per cent in ration } \\
\cline { 3 - 5 } & Pre-starter & Starter & Finisher \\
\hline $\mathbf{1}$ & Crude protein & 23.35 & 21.64 & 20.20 \\
\hline $\mathbf{2}$ & Crude fibre & 3.92 & 3.96 & 3.99 \\
\hline $\mathbf{3}$ & Ether extract & 4.95 & 5.08 & 5.12 \\
\hline $\mathbf{4}$ & Total ash & 6.2 & 6.1 & 5.93 \\
\hline $\mathbf{5}$ & Acid insoluble ash & 1.57 & 1.60 & 1.62 \\
\hline $\mathbf{6}$ & Nitrogen free extract & 61.58 & 63.22 & 64.76 \\
\hline $\mathbf{7}$ & Metabolizable energy $(\mathrm{kcal} / \mathrm{kg})$ & 2982.5 & 3065.7 & 3198.8 \\
\hline $\mathbf{8}$ & E/P ratio & $127.73: 1$ & $141.66: 1$ & $158.35: 1$ \\
\hline
\end{tabular}

Table.2 Average weekly cumulative body weight (g) per bird

\begin{tabular}{llccccc}
\hline Items & & \multicolumn{5}{c}{ Fenugreek seed powder levels } \\
\cline { 3 - 7 } & $0 \%$ & $\begin{array}{r}0.5 \% \\
\left(\mathrm{~T}_{1}\right)\end{array}$ & $\begin{array}{r}1 \% \\
\left(\mathrm{~T}_{2}\right)\end{array}$ & $\begin{array}{r}1.5 \% \\
\left(\mathrm{~T}_{4}\right)\end{array}$ & $\mathrm{SE}$ & $\mathrm{CD}$ \\
\hline Initial & 47.33 & 47.28 & 47.28 & 47.43 & 0.08 & $\mathrm{NS}$ \\
\hline $1^{\text {st }}$ week & 189.50 & 189.25 & 190.15 & 190.25 & 0.86 & $\mathrm{NS}$ \\
\hline $2^{\text {nd }}$ week & 443.33 & 438.38 & 441.56 & 442.47 & 2.63 & $\mathrm{NS}$ \\
\hline $3^{\text {rd }}$ week & $877.50^{\mathrm{a}}$ & $884.54^{\mathrm{a}}$ & $897.48^{\mathrm{b}}$ & $903.44^{\mathrm{b}}$ & 2.76 & 8.51 \\
\hline $4^{\text {th }}$ week & $1388.25^{\mathrm{a}}$ & $1404.57^{\mathrm{b}}$ & $1427.17^{\mathrm{c}}$ & $1428.48^{\mathrm{c}}$ & 2.79 & 8.60 \\
\hline $5^{\text {th }}$ week & $2001.15^{\mathrm{a}}$ & $2035.55^{\mathrm{b}}$ & $2068.56^{\mathrm{c}}$ & $2074.50^{\mathrm{c}}$ & 2.95 & 9.10 \\
\hline $6^{\text {th }}$ week & $2536.47^{\mathrm{a}}$ & $2573.53^{\mathrm{b}}$ & $2624.15^{\mathrm{c}}$ & $2636.12^{\mathrm{c}}$ & 19.65 & 19.65 \\
\hline
\end{tabular}

Note: (Significant $(\mathrm{P}<0.05)$ means under each class in the same column with different superscripts differ significantly) 
Table.3 Hematological analysis under different feeding treatments of fenugreek

\begin{tabular}{|c|c|c|c|c|c|c|}
\hline Preatments & $\mathbf{T}_{1}$ & $\mathbf{T}_{2}$ & $\mathbf{T}_{\mathbf{3}}$ & $\mathbf{T}_{4}$ & $\mathbf{S E}$ & CD \\
\hline $\begin{array}{l}\text { (WBC)White blood } \\
\text { cells }\left(\times 10^{3} / \text { ul }\right)\end{array}$ & $121.83^{b}$ & $122.28^{\mathrm{b}}$ & $129.68^{\mathrm{a}}$ & $130.51^{\mathrm{a}}$ & 0.66 & 2.04 \\
\hline $\begin{array}{l}\text { Lymphocytes } \\
\text { (Volume) }\left(\times 10^{3} / \mathbf{u l}^{\prime}\right)\end{array}$ & $82.19^{b}$ & $82.08^{b}$ & $88.63^{a}$ & $88.73^{a}$ & 0.64 & 1.98 \\
\hline $\begin{array}{l}\text { Monocytes (Volume) } \\
\left(\times 10^{3} / \mathrm{ul}\right)\end{array}$ & $13.15^{\mathrm{c}}$ & $12.45^{\mathrm{d}}$ & $14.04^{\mathrm{a}}$ & $13.48^{\mathrm{b}}$ & 0.19 & 0.27 \\
\hline $\begin{array}{l}\text { Granulocytes } \\
\text { (Volume) }\left(\times 10^{3} / u^{\prime}\right)\end{array}$ & 26.49 & 27.75 & 27.01 & 28.3 & 0.84 & N.S. \\
\hline $\begin{array}{l}(\text { RBC) Red blood } \\
\text { cells } \\
\left(\times 10^{6} / \mathrm{ul}\right)\end{array}$ & $2.44^{\mathrm{a}}$ & $2.14^{\mathrm{b}}$ & $2.10^{\mathrm{b}}$ & $2.05^{\mathrm{b}}$ & 0.06 & 0.20 \\
\hline $\begin{array}{l}\text { (Hb) Hemoglobin } \\
(\mathrm{g} / \mathrm{dl})\end{array}$ & $12.29^{\mathrm{a}}$ & $10.95^{b}$ & $10.38^{b}$ & $10.86^{\mathrm{b}}$ & 0.24 & 0.74 \\
\hline $\begin{array}{l}\text { (HCT) Hematocrit } \\
(\%)\end{array}$ & $32.53^{\mathrm{a}}$ & $28.40^{\mathrm{b}}$ & $27.78^{b}$ & $27.73^{b}$ & 0.57 & 1.76 \\
\hline $\begin{array}{l}\text { (MCV) Mean } \\
\text { corpuscle volume (fl) }\end{array}$ & 137.96 & 134.58 & 133.55 & 133.11 & 1.42 & N.S. \\
\hline $\begin{array}{l}\text { (MCH) Mean } \\
\text { corpuscle } \\
\text { Hemoglobin } \\
\text { (pg) }\end{array}$ & $32.06^{\mathrm{b}}$ & $39.73^{\mathrm{a}}$ & $39.85^{\mathrm{a}}$ & $32.14^{\mathrm{b}}$ & 2.22 & 6.48 \\
\hline $\begin{array}{l}\text { (MCHC) Mean } \\
\text { corpuscle } \\
\text { Hemoglobin } \\
\text { concentration }(\mathrm{g} / \mathrm{dl})\end{array}$ & $37.76^{b}$ & $37.50^{b}$ & $37.86^{\mathrm{b}}$ & $39.35^{\mathrm{a}}$ & 0.35 & 1.08 \\
\hline $\begin{array}{l}\text { (PLT) Platelet } \\
\left(\times 10^{3} / \mathrm{ul}\right)\end{array}$ & 187.50 & 318.00 & 225.63 & 245.25 & 37.88 & N.S. \\
\hline
\end{tabular}

Note: (Significant $(\mathrm{P}<0.05)$ differences are shown for the mean having variable superscript within a row) 
Table.4 Effect of dietary treatment of fenugreek seed on serum constituents of broiler chicks

\begin{tabular}{|l|c|c|c|c|c|c|}
\hline \multicolumn{1}{|c|}{ Treatments } & $\mathbf{T}_{\mathbf{1}}$ & $\mathbf{T}_{\mathbf{2}}$ & $\mathbf{T}_{\mathbf{3}}$ & $\mathbf{T}_{\mathbf{4}}$ & $\mathbf{S E}$ & $\mathbf{C . D}$ \\
\hline Parameter & & & & & & \\
\hline Glucose (mg/dl) & $124.38^{\mathrm{c}}$ & $136.38^{\mathrm{b}}$ & $146.38^{\mathrm{a}}$ & $149.00^{\mathrm{a}}$ & 3.45 & 10.64 \\
\hline Cholesterol (mg/dl) & 133.88 & 154.75 & 123.38 & 142.25 & 7.20 & N.S. \\
\hline $\begin{array}{l}\text { Triglyceride } \\
\text { (mg/dl) }\end{array}$ & $219.50^{\mathrm{a}}$ & $206.25^{\mathrm{a}}$ & $118.38^{\mathrm{ab}}$ & $93.63^{\mathrm{b}}$ & 33.52 & 103.31 \\
\hline $\begin{array}{l}\text { HDL (High density } \\
\text { lipoprotein) (mg/dl) }\end{array}$ & $62.38^{\mathrm{b}}$ & $90.50^{\mathrm{a}}$ & $77.38^{\mathrm{a}}$ & $79.88^{\mathrm{a}}$ & 4.29 & 13.23 \\
\hline $\begin{array}{l}\text { LDL (Low density } \\
\text { lipoprotein) (mg/dl) }\end{array}$ & 26.00 & 34.13 & 31.13 & 37.88 & 2.69 & N.S. \\
\hline LDL / HDL Ratio & 0.42 & 0.37 & 0.33 & 0.47 & 0.03 & N.S. \\
\hline
\end{tabular}

Note: (Similar superscript do not differ significantly $(\mathrm{P}<0.05)$ from each other within a row)

\section{Serum constituents}

The result prsented in Table 4. The blood biochemical data shows that the herbal feed additive used in this experiment have noteworthy effect on their lipid metabolism. The serum glucose for $\mathrm{T}_{1}(124.38 \mathrm{mg} / \mathrm{dl})$ control group fed without fenugreek seed powder was the lowest followed by group $\mathrm{T}_{2}$ $(136.38 \mathrm{mg} / \mathrm{dl})$ fed 0.5 per cent fenugreek seed powder, $\mathrm{T}_{3}(146 \mathrm{mg} / \mathrm{dl})$ fed 1 per cent fenugreek seed powder group and highest in $\mathrm{T}_{4}(149 \mathrm{mg} / \mathrm{dl})$ fed 1.5 fenugreek seed powder group.

The serum cholesterol for $\mathrm{T}_{3}(123.38 \mathrm{mg} / \mathrm{dl})$ group fed 1 per cent fenugreek seed powder was the lowest followed by group $\mathrm{T}_{1}$ control group $(133.88 \mathrm{mg} / \mathrm{dl})$ fed without fenugreek seed powder, $\mathrm{T}_{4}(142.25 \mathrm{mg} / \mathrm{dl})$ fed 1.5 per cent fenugreek seed powder group and highest in $\mathrm{T}_{2} \quad(154.75 \mathrm{mg} / \mathrm{dl})$ fed 0.5 fenugreek seed powder group. The broilers in $\mathrm{T}_{3}$ group recorded lower cholesterol than $\mathrm{T}_{1}$, $\mathrm{T}_{2}$ and $\mathrm{T}_{4}$ groups. Serum triglyceride content was significantly $(\mathrm{P}<0.05)$ low in $\mathrm{T}_{4}(93.63$ $\mathrm{mg} / \mathrm{dl})$ than in $\mathrm{T}_{3}$ group $(118.38 \mathrm{mg} / \mathrm{dl}), \mathrm{T}_{2}$ $(206.25 \mathrm{mg} / \mathrm{dl})$ and $\mathrm{T}_{1}(219.50 \mathrm{mg} / \mathrm{dl})$. The HDL value was highest in $\mathrm{T}_{2}$ group (90.50) and lowest in $\mathrm{T}_{1}$ control group (62.38) and values in $T_{3}$ and $T_{4}$ were 77.38 and 79.88 respectively. The LDL value was lowest in $\mathrm{T}_{1}$ control group (26 mg/dl) than other groups in $\mathrm{T}_{2}, \mathrm{~T}_{3}$, and $\mathrm{T}_{4}$ group $(34.13,31.13$ and 37.88) respectively. The LDL/HDL ratio values was higest in $\mathrm{T}_{4}$ group. The $1 \%$ fenugreek seed powder lowering the cholesterol level because of their properties.

Duru et al., (2013) also reported the same findings and stated that if the level of Fenugreek seed increased above $20 \mathrm{~g} / \mathrm{kg}$ broiler diet causes decreased triglyceride and cholesterol levels but increased the LDL cholesterol and glucose. Al-Habori (1998) found that fenugreek and its extract reduced the levels of cholesterol, triglycerides, and low density lipoprotein (LDL-cholesterol) with no effect on high density lipoprotein (HDL-cholesterol). This selective reduction in LDL-cholesterol results in the improvement of the ratio of HDL- cholesterol to LDLcholesterol. Weerasingh and Atapattu (2013) and Momoun et al., (2014) reported that serum cholesterol levels were reduced when fenugreek was added in diet of broilers and increasing the triglyceride level in broilers. Whereas, Safaei et al., (2013) reported that effect of fenugreek extract in drinking water on some blood parameter like triglyceride, 
cholesterol, and glucose levels were significantly different among the treatments when compared to the control group.

Ii is concluded that the inclusion of 1.5 per cent of fenugreek seed powder in broiler diet as a herbal feed supplement is beneficial in improving the live weight of broilers. The inclusion fenugreek seed powder in broiler ration increased white blood cells for strong immunity, lymphocytes and platelet count and improved the overall hematological parameter.The inclusion of fenugreek seed powder in broiler ration substantially decreased serum cholesterol, triglyceride and increased the glucose level and improved the LDL/HDL ratio. It is beneficial to use fenugreek as a growth promoter or feed supplement in commercial broiler production.

\section{References}

Abaza I.M. (2007). Effects of using fenugreek, chamomile and radish as feed additives on productive performance and digestibility coefficients of laying hens. Poult. Sci, 199-218.

Abdel-Rahman H.A., Fathallah S.I.,Helal M.A., Nafeaa A.A., and Zahran I.S., (2014). Effect of turmeric (Curcuma longa), fenugreek (Trigonella foenum graecum L.) and bioflavonoid supplementation to the broiler chicks diet and drinking water on the growth performance and intestinal morphometric parameters. Global veterinarian., 12(5): 627-635.

Abdul Rahman S. Y. (2012). Effect of fenugreek seeds on some physiological characters in broiler breeders males, Mesopotmia J. Agri., 40(2) 42-47.

Aboul-Fotouh, GE; Shehat S.M. and AbdelAzeem S. N. (1999). Effect of some medicin- al plants as feed additives on performance of growing sheep Egyptian j. $N$ - utrition and feeds, 2(2): 79-87

Al-Habori M., Al-Aghbari A. M., and AlMamary. M (1998). Effects of fenugreek seeds and its extracts on plasma lipid Profile: A study on rabbits Phytotherapy Res., (12)572-575.

Anonymous (2012). $19^{\text {th }}$ Livestock Census of India Government of India New Delhi. A.O.A.C. (1995). Official Methods of Analysis, $16^{\text {th }}$ ed. Association of Official Analytical Chemist, Washington D.C.

Bhaisare, B. D. and D. Thyagarajan (2014). Effect of Four Herbal Seeds on Blood Parameters in Turkey Poults.Indian J. Small Rumin., 3(8): 112-123.

Bhale C.T. (2015). Effect of germinated Fenugreek (TrigonellaFoenumGraecum.L) Seed Powder on Performance of Broiler Chicken. M. V.Sc. Thesis, Submitted to MAFSU, Nagpur (M.S).

Duru, M., Z. Erdogan, A. Duru, A. Kucukgul, V. Duzguner, D.A. Kaya and A. Sahin (2013). Effect of seed powder of a herbal legume fenugreek on growth performance, body components, digestive parts, and blood parameters of broiler chicks. Pakistan J. Zoo., 45(4): 1007-1014.

Mamoun, T., M. A. Mukhtar and M.H. Tabidi (2014). Effect of fenugreek seed powder on the performance, carcass characteristics and some blood serum attributes. Adv. Res. Agri. Vet. Sci.,1(1): 6-11.

Mukhtar Ahmed Mukhtar,Tariq Mamoun and Mohamed H Tabidi (2014). Effect of fenugreek seed powder on the performance, carcass characteristics and some blood serum attributes. Advance Research in Agriculture and Veterinary Science, 1(1): 6-11.

Nazar A. Nasari and Tinay E.I. (2007). Functional properties of fenugreek (Trigonella foenumgraecum) protein 
concentrate. Food Chemistry 103(2): 582-589.

Safaei, A, S. M. rahanjam and M. Gharajanlu (2013). Effect of foenum-graecum on immune response and some blood parameters of broilers. Scholarly $J$. Agri. Sci., 3(4):117-120.

Snedecor,G.W. and W.G. Cochran, (1982). Statistical Methods. 6th Edition, Oxford and IBH Publishing co. Culcutta, Bombay and Delhi: 168-181.

Weerasingha A.S. and Atapattu N.S.B.M. (2013). Effect of fenugreek (Trigonella foenum-graecum $L$.) seed powder on growth performance, visceral organ weight, serum cholesterol levels and the nitrogen retention of broiler chicken,
Tropical Agricultural Research, 24(3): 289-295.

Yasar, J., S Khan, N. Chand, M. Mushtaq, A. Sultan and Rafiullah (2012). Comparative efficacy of different schedules of administration of medicinal plants mixed infusion on hematology of broiler chicks. J. Agric. Sci., 28(2): 78-84.

Yatoo, M. A., R.K. Sharma, N. Khan, A. Rastogi, and A. K. Pathak (2012). Effect of fenugreek and black cumin seeds as feed additives on blood biochemical profile and performance of broilers. Indian J. Anim. Nutri., 29(2): 174-178

\section{How to cite this article:}

Gaikwad, B.S., R.A. Patil, P.V. Padghan and Shinde, S.S. 2019. Effect of Fenugreek (Trigonella foenum-gracum L.) Seed Powder as Natural Feed Additive on Performance and Blood Parameters of Broiler Chicks. Int.J.Curr.Microbiol.App.Sci. 8(10): 1147-1155. doi: https://doi.org/10.20546/ijcmas.2019.810.134 